\title{
APPLICATION OF NATIONAL MOVEMENT GAMES IN PHYSICAL EDUCATION CLASSES
}

\author{
Pardayev B.P.
}

Lecturer, Scientific And Methodological Provision Of Physical Education And Sports Specialists Under The Ministry Of Physical Training And Sports Of The Republic Of Uzbekistan

\section{ABSTRACT}

This article provides a range of information and guides on how to teach movement games to schoolchildren of all ages and ensure their effective and healthy growth. In addition, teachers were instructed to organize different movement games for different classes of students from time to time during the lesson.

KEYWORDS: - Movement games, physical fitness, sport games, lessons, schoolchildren, gymnastics, and trainings.

\section{INTRODUCTION}

In the school program of physical education it is planned to hold movement games in physical education classes of all classes, which will be selected by the teacher in the classroom, taking into account the age characteristics of students.

In secondary schools, in the classroom, extracurricular activities - sports and the organization of public sports activities with children - play games play an important role.

In the classroom, movement games are combined with other means of physical education - gymnastics, athletics, sports, trainings.

The use of games in the middle of classes and during extended breaks, school holidays and other events can improve the general physical fitness in the sports sections of the games, as well as improve the physical quality and movement skills required for this or that sport.

In the primary grades, special "play tools" conducted by class teachers have a great educational value, and their task is to provide active recreation, which helps children to develop physically.

School teachers strive to introduce good games into children's daily lives and help make it popular in out-of-school educational institutions.

The content of the game, the organization and methodology of its conduct depends on the task, the order of the participants, the form of training with children (in class, break, section, on holidays).

In the classroom, movement games are combined with other means of physical 
CURRENT RESEARCH JOURNAL OF PEDAGOGICS 2(8): 96-100, August

2021 DOI: https://doi.org/10.37547/pedagogics-crjp-02-08-22

ISSN 2767-3278

(C)2021 Master Journals

\section{Crossref do) 81 Google}

Accepted 26 ${ }^{\text {th }}$ August, 2021 \& Published $31^{\text {th }}$ August, 2021

education - gymnastics, athletics, and sports, cross-country training.

Games are used between classes and during extended breaks, school holidays and other events, to increase general physical fitness in sports sections, as well as to improve the physical quality and movement skills required for other sports.

In the primary grades, special "play tools" conducted by class teachers have a great educational value, and their function is to create active recreation that helps children to develop physically.

School physical education teachers try to introduce fun games into children's daily lives and help make it popular in out-of-school educational institutions.

The content of the game depends on the organization and methodology of its conducted task, the order of the participants, form of the training with children (in class, break, section, on holidays).

Lesson games. In physical education games, movement games play a major role among other means of physical education, especially in small classes. In the middle and especially large classes, movement games give up the main place to gymnastics.

In physical education classes, movement games are used to solve educational, pedagogical and health-improving tasks in accordance with the requirements of the physical education program for students of I-XI grades.

\section{Educational responsibilities include:}

Running, jumping, throwing, and other movement skills strengthen and improve medical skills, as well as gymnastics, athletics, sports, and cross-country training.

Educational tasks include: Training physical qualities (speed, agility, endurance, strength, and flexibility), public, honesty and other moral, as well as willpower qualities.

They help children to form and develop normally, strengthening their health.

The choice of game depends on the pedagogical task set by the teacher before the lesson.

For example, if the task of the lesson is to improve the skills of young school-age children in running and long jump, then the "Wolf in the ditch" game can be used. You can solve the task of throwing the ball from the chest and strengthening the skill of two supports from above "Did you pass the ball-sit" or "Opposite" relay game to.

In solving the educational task, it is also considered that the improvement of physical quality at the same time affects the physical development of students in the community.

Educational and pedagogical tasks are closely interrelated. Similarly, in the game, for example, improving the skills of high jump in the game teaches students to believe in their own strength, courage, bravery. Therefore, in setting the task, different aspects of a single educational process are taken into account.

The choice of action games for the lesson will also depend on the composition of the students (age, gender, readiness), the place of the lesson (playground, hall, school hallway), equipment and facilities. In solving one and the same pedagogical task, depending on the working conditions, different games can be used.

Similarly, for example, in a game with students in grades 1-2, the task of training the speed of selfreaction - when the task is set, "Everyone has their own flag" (if the lesson is on the field or in the hall), or "All in place" (if the lesson is held in the school hallway or in the hall). Before the lesson - to improve the throwing and catching the ball, to the lessons of grades 3-4 "Did you pass - sit", "Hunters and ducks", "Do not give the 
CURRENT RESEARCH JOURNAL OF PEDAGOGICS 2(8): 96-100, August

2021 DOI: https://doi.org/10.37547/pedagogics-crjp-02-08-22

ISSN 2767-3278

(C)2021 Master Journals

\section{Crossref do) 81 Google}

Accepted 26 ${ }^{\text {th }}$ August, 2021 \& Published $31^{\text {th }}$ August, 2021

ball to the head of the game", In the lesson for 5 th and 6th grades, you can include the games "On the ball", "Shooting", "Fight for the ball".

It takes a more complex situation to master a certain skill in the game: increasing the number of rules complicates it, complicating the interaction of the games.

The game requires certain qualities, skills and abilities from the participants. This is not possible, for example, if students are given a "catch the ball" game if they throw and catch the ball, carry the ball, speed up the movement, catch the ball when they are close to each other with the opponent it is very necessary to obtain that minimum amount of bending.

These qualities, skills and abilities are improved, enriched, strengthened in the game.

Included in the game, each type of movement must first be trained in specific exercises by the trainees. In small school-age children, the most basic should consist of more natural and elementary movements. They can be introduced into the game without prior training.

So, for example, when children are asked to play the game "Wolf in the ditch", it is not necessary to teach them to run and jump in length beforehand, because children make this jump in the game based on their movement experiences. The teacher's task is to draw the children's attention to the fact that they can jump well and correctly during the game.

When conducting movement games methodically correctly, children can acquire elementary movement skills in performing certain movements. The physical quality, which is necessary for him or her to master any other skill well, is developed in time when students use this exercise in the game process.

If the student is unable to behave in the game, the game is brought up using a gradual way of complicating: the introduction of new complex rules of the game, the elements of interaction of players at the beginning of all-powerful or universal it requires complex interactions from participants that are relevant to the capabilities of the learners and the structure of the organization.

As in physical education classes, movement games are combined with other physical education tools, it is very important to correctly determine the position of the game in the classroom between other exercises.

Game planning should follow the list of games given by grades throughout the year in the physical education curriculum of secondary schools. The list of given games should be added and changed by the teacher to the school based on the working conditions, i.e. to the preparation of the trainees, the place or room for training, taking into account the equipment on the scale, mainly for sports. The working conditions of each quarter must be taken into account when dividing the game into quarters. In the first and fourth quarters, you will have the opportunity to practice on the school grounds, in the open air. Therefore, in these quarters, when it takes a lot of space, it makes sense to plan games. ("Homeless Rabbit", "Everyone to the Flag", "Zuv-Zuv", "Forty Stones"). In the second and third quarters, it is necessary to plan games that do not require a large space when the training is held indoors.

At the end of each term, control exercises for each class are identified and accepted. As control exercises you can put separate games in grades 1-2. In this game, students' skills, speed and coordination of movement, clear targeting, speed of reaction and other qualities and skills are most needed to solve the task set by the teacher, and this or that should be more convenient to account for games.

The teacher should also consider ways to test students' movement skills and ability to do 
CURRENT RESEARCH JOURNAL OF PEDAGOGICS 2(8): 96-100, August

2021 DOI: https://doi.org/10.37547/pedagogics-crjp-02-08-22

ISSN 2767-3278

(C)2021 Master Journals

Crossref do: 81 Google

Accepted $26^{\text {th }}$ August, 2021 \& Published 31 th August, 2021

something in a moving game. The number of games given per year will depend on the teaching and learning task offered for each class, depending on the readiness and working conditions of the students. About 80-85 games a year are recommended for students in grades 12. 40-50 games for students in grades 3-4 and 30-40 games for students in grades 8-11. can be. This song also includes repetition and teaching new games. The game is not evenly distributed over the quarters, but depends on the length of the quarter and the task assigned to it. The new game material will be taught mainly at the end of the first, second and third quarters. It is strengthened by changing the games played at the beginning of the first quarter and the previous school year, or by passing on another option. In the fourth quarter, it will be strengthened and the games of the current academic year will be complicated. When planning quarters for similar lessons, it is important to keep in mind the sequence of the game and its repetition. It is necessary to acquaint students in advance with the technical methods in order to strengthen the right skills. Then this method should be taught to students in a simplified way. Only after this learned method can you enter the game. The sudden change of situation in a moving game helps to bring the taught method closer to the conditions of a sports game.

\section{REFERENCES}

1. Umarov M.N. Gymnastics. -T .: Vneshinvestprom, 2015. - 156 p.

2. Eshtaev A.K. Gymnastics lesson. - Tashkent. UzDJTI, 2004. - 253 p.

3. Umarov M.N, Eshtayev AK, Ishtayev D.R, Toy'chiyev Z.O'., Eshtayev S.A, Pakhrudinova N.Yu. Theory and methodology of gymnastics. - $\mathrm{T}$.: Barkamol fayz media, 2017. - 242 p.

4. Abdullaeva B.P. Corruption in the field of education: assessments and ways to address. “Тенденции и перспективи развития науки и образования в условиях

глобализации".Международной научнопрактической интернет-конференции. г.Переяслав, Украина.2020 год 30

5. Abdullaeva B.P. Babaraximova B.P. Pardaev B.P.Using information and communication technologies in teaching process of various primary European Journal of Research and Reflection in Educational Sciences, 8 (10), 67-70. Progressive Academic Publishing, UKwww.idpublications.org 14.10.2020.

6. Abdullaeva B.P. Abdullaev F.T. Organization of Swimming Lessons In Preschool Institutions THE AMERICAN JOURNAL OF SOCIAL SCIENCE AND EDUCATION INNOVATIONS. JULY 2020[ TAJSSEI]322ISSN (e):2689-100X DOI: https://doi.org/10.37547/tajssei/Volume0 2Issue 07-423.

7. Abdullayeva, B.P., \& Babaraximova, B. P. (2020). MAKTABGACHA TA'LIM MUASSASASIDA FUTBOL DARSLARINI TASHKIL ETISH METODIKASI. Academic Research in Educational Sciences http://ares.uz/jurnallar-sahifasi/ares-vol1-no-3-2020.

8. Abdullaeva B.P. ACADEMICIA: An International Multidisciplinary Research Journal https://saarj.com ORGANIZATION AND METHODOLOGY OF CONDUCTING FOOTBALL LESSONS IN A PRESCHOOL INSTITUTION 650-655 10.5958/22497137.2021 .00098 .

9. Abdullaeva B.P. Teaching A Child To Play Football From A Youth. The American 
CURRENT RESEARCH JOURNAL OF PEDAGOGICS 2(8): 96-100, August

2021 DOI: https://doi.org/10.37547/pedagogics-crjp-02-08-22

ISSN 2767-3278

(C)2021 Master Journals

Crossref dof 81 Google

Accepted 26 $6^{\text {th }}$ August, 2021 \& Published 31 thAugust, 2021

Journal of Interdisciplinary Innovations

and Research (ISSN-2642-7478)

Published: April 30, 2021. Pages:147-151

Doi:https://doi.org/10.37547/tajiir/Volum

e03Issue04-24MPACT

FACTOR2021:5.6760CLC-1091588944. 